\title{
DETERMINATION OF SOME PESTICIDE RESIDUES ON SOME OILY CROPS.
}

Ghazy, Yasmin A.; O.C. Bayomi*; F.A.H. Shaheen** and

A.A.A. Said ${ }^{\star \star}$

* Agric. Pesticides Department, Fac. Of Agric., Mansoura University.

** Agric. Pesticides Dept., Fac. Of Agric., Kafer El-Sheikh University.

\begin{abstract}
The present study was carried out to investigate the toxic effect of some pesticides (Lambda-cyhalothrine, methomyl, Carbofuran, Chloropyrifos and Mancozeb) against cotton leaf worm Spodoptera Littoralis. Different samples of peanut, linseed and sunflower seeds were collected, extracted, cleaned up, to use in different studies (toxicity analytical and determination joint action effect of oil peanut extracted with pesticides against $S$. Littoralis. The pesticides residues mixed with oil extracted, were determined using biochemical's parameters (Acetyl cholinesterase activity). Thin-layer chromatography was used to separate the tested pesticides from each compound. RF values for the tested compounds were recorded alone and in their mixtures with non treated oils. Pesticides residues extracted from the treated samples of peanut, linseed and sunflower seeds oil were determined after studying their effects on Acetyl cholinesterase activities. Results showed that Chloropyrifos insecticide was the most potent compound followed by Lambda-cyhalothrin, Methomyl and Carbofurn. Mancozeb and oil peanut have no toxic effect on S. Littoralis. The joint action effects resulting form mixing oil peanut with each of the tested compounds are shown that synergism was noticed with oil peanut in combination with Methomyl, Chloropyrifos and Lambda respectively.
\end{abstract}

\section{INTRODUCTION}

Oils are widely used by people in their food also Egyptian people use oils in preparing most kinds of food. Egypt imports food oil for about $85 \%$ of domestic consumption. Peanut, linseed and sunflower are considered from the most important oil crops in the world, as seeds contain about $40-60 \%$, $32-42 \%$ and $25-30 \%$ oil respectively. So it is important to conduct essential studies to determine the residues of chemical pesticides at some oil crops from their oil. Oily crops were chosen for this purpose because they used as animal feed and their oils are widely used in flavoring food products in addition beverages, the pharmaceutical purposes, perfume and cosmetic industries (Swisher and Prichett, 1969), (Coste et al. 1968).

As known oily crops are attacked by several diseases and insects. One of the most harmful insects is cotton leaf worm, Spodoptera Litoralis (Biosd) in the case of peanut crop. Therefore this insect considered widespread and serious therefore, many farmers used different pesticides against it which lead to pesticide hazards such as residues and environmental pollution.

"consequently, the aim of this study investigated the:-

Insecticidal activity of some pesticides and their mixtures with oil peanut against Spodoptera Littoralis using different toxicological tests. In addition the 
Ghazy, Yasmin A. et al.

determination of pesticide residues in oily crop seeds (peanut, linseed and sunflower). The side effect of the residues of the tested pesticides on acetylcholine esterase (AchE) activity was also studied.

\section{MATERIALS AND METHODS}

\section{1- Pesticides used:}

Methomyl (methyl $\mathrm{N}-\{[($ methylamine) carbonyl]oxy $\}$ ethanimidothioate) ,Furadan( 2, 3-dihydro-2, 2-dimethyl-7-benzofuranyl methyl crbamate) ,lambada cyhalothrine (cyano(3-phenoxyphenyl)methyl (1R,3R)-rel-3-[(1Z)-2chloro-3,3,3-trifluoro-1-propenyl]-2,2-dimethylcyclo propane carboxylate ,chlropyrifps ( O,O-diethyl O-(3,5,6-trichloro-2-pyridinyl)Phosphorothioate) and Mancozeb (\{[1,2-ethanediylbis [carbamodithioato]](2)\}manganese mixture with $\{[1,2-$ ethanediylbis [carbamodithioato]](2-)\}zinc.

\section{2- Bioassay tests}

2-1- Rearing insects for bioassay tests:

A-cotton leaf worm (Spodoptera littoralis)

A susceptible strain of cotton leaf worm, Spodoptera littoralis (Biosd) reared several generation on castor oil-bean leaves (Ricinous communis L.) under laboratory condition of $25 \pm 5 \stackrel{\circ}{\circ} \mathrm{C}$ and $65 \pm 5 \%(\mathrm{RH})$. The Egyptian cotton leaf worm was reared as described by El-defrawi et al. (1964).

2-2- Toxicity tests for insecticides used:

\section{2-2-1- leaf dipping technique:}

The fourth instar larvae of Spodoptera littoralis were chosen for dipping tests. Pesticides were prepared at different concentrations in the rang of (5$1000 \mathrm{ppm}$ ) on water solutions. While 2,4 , and $6 \%$ of oil peanut were used with acetone solution. The peanut leaves were immersed in dilution of different concentrations for five seconds, each treatment was replicated four times (for each concentration). Leaves were left to dry then ten larvae of approximately similar weight were allowed to feed for 24 hours at constant laboratory conditions. Mortalities were recorded after $24 \mathrm{hrs}$. Control was made by the same methods but using distilled water or water treated by acetone. Mortalities were corrected according to Abbott's Formula (1925). Calculation of $\mathrm{LC}_{50}$ values confidence limits, and slope values of the regression lines were corrected according to the statistical method of Litchfield and Wilcoxon (1949).

\section{2-2-2- joint action effect mixture between oil peanut extract and insecticide:}

The joint action of binary mixture of peanut oil with each insecticide against spodoptera littoralis was tested after the determination $\mathrm{LC}_{50}$ values of each compound. Mixtures of oil peanut $(1 \%)$ with each pesticide were prepared at the ratio of $\mathrm{LC}_{50}$ values. Insect mortalities were recorded after 24 hours. Percentages of mortality values were corrected according to Abbott's Formula (1925) and LC 50 were calculated using the statistical method of Litchfield and Wilcoxon (1949). 


\section{3- Chemicals analysis tested: \\ 3-1- Extraction method}

Fresh seeds Peanut, sunflower, linseed were collected. Fifty gram untreated and or treated (peanut, linseed and sunflower) seeds were taken then were crushed in blender and sieved to obtain powder $50 \mathrm{gm}$ so much of the product. Seeds powder was soaked in $150 \mathrm{ml}$ of hexane for 48-72 hrs, and was shacked four hours the solutions were filtered on G4 filter under vacuum in a rotatory evaporation. The solid phase was washed with $50 \mathrm{ml}$ hexane three times. The combined filtrates were taken and evaporated in rotatory evaporator to dryness. The resulted oil extract was transferred to 500 $\mathrm{ml}$ separator funnel and extracted with methylene chloride (1:3) twice. The methylene chloride phase was evaporated to dryness using rotatory evaporator and then the residues were dissolved in $2 \mathrm{ml}$ ethyl acetate and were then kept for experimental tests (Bayoumi et al. 1997).

\section{4-1- Thin-Layer Chromatographic (T.L.C) analysis:}

\section{4-1-1- preparation of T.L.C plates.}

According to Bayoumi (1983) Laboratory - made chromatoplates $(15 \times 7.5) \mathrm{cm}$ were prepared by mixing $2 \mathrm{gm}$ of silica gel with $4 \mathrm{ml}$ of distilled water in a small conical flask, and by shaking vigorously for exactly $90 \mathrm{sec}$. The slurry was poured on the plate with upper end of the central glass plate and was spread evenly over the plate with a manual spreader chromatoplates, then were dried for 5 minutes in air at $21 \pm 4^{\circ} \mathrm{C}$ and then in an oven at $105^{\circ} \mathrm{C}$ for 15 minutes. Plates were allowed to cool down and were exposed to air at $21 \pm 4^{\circ} \mathrm{C}$ for a pout $30 \mathrm{~min}$.

Different solvent systems were used for separating insecticides, oil extracted and their mixtures with tested pesticides. Detection reagent was iodine vapor.

\section{5- Determination of insecticides used:}

\section{5-1- extraction of pesticides from Thin Layer Chromato-plates:}

The recovery percentage of pesticides were scrapped and extracted by stirring in a test-tube with a $3 \mathrm{ml}$ acetone for one minute. The tube was rinsed twice with $1 \mathrm{ml}$ of acetone and transferred to the glass filter G4. The residue on the filter glass was washed twice with $1 \mathrm{ml}$ acetone and filtered under vacuum, the combined filtered was evaporated to dryness and then recovered in $5 \mathrm{ml}$ ethyl acetate. The previous solutions were suitable for UV-spectrophotometer analysis according to Bayoumi (1983)

\section{5-2- Qualitative analysis:}

Different concentrations of methomyl, lambda-cyhalothrin, chloropyrifos, furadan and mancozeb (corresponding to 5, 10, 20, 40 and $100 \mu \mathrm{g}$ ) using a stock solution of $1 \mu \mathrm{g} / \mu \mathrm{l}$ acetone. The mean RF values of detectable spots were recorded for each sample. Each assay was replicated at least three times.

\section{5-3- Semi quantitative analysis:}

The bands corresponding to the insecticides were isolated, concentrated and respotted after extraction on TLC-plates to determine approximately the concentration and the presence of each compound tested in the samples used. 
Ghazy, Yasmin A. et al.

5-4- Detection method:

lodine vapor:-

lodine vapor was prepared according to the method of Bayoumi (1983)

by adding $2 \mathrm{ml}$ of diluted $\mathrm{H}_{2} \mathrm{SO}_{4} 33 \%$ to $5 \mathrm{gm}$ of granulated $\mathrm{I}_{2}$ in a glass jar. The detection limit was determined by using different concentrations of tested compounds. The detectable spots were recorded for each compound as $\mathrm{Rf}$ values at intervals with a minimum time of 15 minutes.

6- Biochemical assays:

6-Determination of cholinesterase activity

Waber, H. D. M. W. (1966). Kinetic colorimetric method for cholinesterase activity. 91: 1927.

\section{RESULTS AND DISCUSSION}

\section{1- Extraction of oil from seeds}

Table (1) represent the oil percentages obtained from peanut, linseed and sunflower seeds after extraction and clean up methods applied under laboratory condition. From this Table it was evident that the highly oil content was obtained with peanut oil folwed by linseed and sunflower respectively. So this study was directed to find the effect of peanut oil on different pesticides activities against cotton leaf worm Spodoptera Littoralis.

Table (1): oil content and its percentage extracted from different seeds of peanut, linseed and sunflower.

\begin{tabular}{|c|c|c|c|}
\hline Source of seeds & $\begin{array}{c}\text { Weight of fresh } \\
\text { seeds sample (g) }\end{array}$ & $\begin{array}{c}\text { Weight of } \\
\text { extracted oil (g) }\end{array}$ & $\begin{array}{c}\text { Percent of extracted } \\
\text { oil (\%) }\end{array}$ \\
\hline 1- Peanut & 500 & 2.8 & 0.581 \\
\hline 2- Linseed & 500 & 2.4 & 0.498 \\
\hline 3-Sunflower & 500 & 1.9 & 0.394 \\
\hline
\end{tabular}

2- Toxicity of some pesticides against Spodoptera littoralis:

Different pesticides were tested against the $4^{\text {th }}$ instar larvae of $S$. Littoralis From the results depicted in Table (2) chloropyrifos was the most potent compound followed by lambda-cyhalothrin, methomyl and furdan. While the fungicide mancozeb showed no effect against $S$. Littoralis. The previous results agree with that obtained by Gupta et al. (1986) Watson et al. (1983) and Souza et al. (1992) for methomyl, chloropyrifos and lambdathyhalothrin

3- Joint Toxic effect of peanut oil with some pesticides on Spodoptera littoralis larvae:

Table (3) showed synergetic effect against $S$. Littoralis larvae, the highest synergistic effect was obtained in the case of the mixing between methomyl and peanut oil, the percentage mortality was $86 \%$ after 24 hours. 
J. Agric. Sci. Mansoura Univ., 33(5), May, 2008

Table (2) - Toxic effect of different pesticides on S. littoral

\begin{tabular}{|c|c|c|c|c|}
\hline \multirow[b]{2}{*}{ Pesticides } & \multirow{2}{*}{$\begin{array}{l}\text { LC50 } \\
\text { P.P.m }\end{array}$} & \multicolumn{2}{|c|}{ Confidence limits $95 \%$} & \multirow[t]{2}{*}{ Slope } \\
\hline & & Lower & Upper & \\
\hline methomyl & 191.6 & 151 & 238 & 0.891 \\
\hline Lambda & 46.18 & 1983 & 4549 & 0.640 \\
\hline Furdan & 1559 & 841 & 17022 & 1.042 \\
\hline Mancozeb & $>2000$ & & & \\
\hline Chloropyrifos & 9.70 & 6 & 12 & 0.723 \\
\hline
\end{tabular}

Table (3): The percent of mortality of binary mixture (pesticide + oil peanut) on Spodoptera littorals.

\begin{tabular}{|c|c|c|c|}
\hline Binary mixture & $\begin{array}{c}\text { Caculated LC50 } \\
\text { concentration (ppm) }\end{array}$ & $\begin{array}{c}\text { Oil peanut } \\
(\%)\end{array}$ & $\begin{array}{c}\text { Mortality } \\
(\%)\end{array}$ \\
\hline 1- methomyl + oil peanut & 191.6 & 1 & 86 \\
\hline 2- chloropyrifos + oil peanut & 9.70 & 1 & 83 \\
\hline 3- lambda + oil peanut & 46.18 & 1 & 73 \\
\hline
\end{tabular}

\section{4- Thin layer chromatographic analysis of insecticides and oil extracts:}

From the RF values presented in table (4), it was evident that the best over all separation of these insecticides (Methomyl, Lambda-cyhalothrin, Furdan, Mancozeb, Chloropyrifos) were obtained by using acetone: ethyl acetate: chloroform (0.5: 1.5: 3). Table (5) showed that, there is no interference or changes were found in the RF values of the different compounds alone or in their mixtures with the peanut, linseed and sunflower oils. Also each oil extracted from peanut seed, linseed and sunflower seed were spotted on thin layer chromatoplates and fractionated by using two solvent systems. After detection of the developing plates were treated with lodine vapors for recording the RF values of these compound our results were similar to that obtained by Bayoumi et al. (1983), Bayomi and Ibrahim (1988) and ashry et al. (1991).

Table (4): Thin-layer chromatographic analysis of the compounds tested Using different solvent system*.

\begin{tabular}{|l|c|c|c|c|c|c|}
\hline \multicolumn{7}{|c|}{ RF values } \\
\hline Solvent systems used & $\begin{array}{c}\text { Ratio } \\
\text { (v:v) }\end{array}$ & Lannate & Lambda & $\begin{array}{l}\text { Chloro- } \\
\text { pyrifos }\end{array}$ & $\begin{array}{c}\text { Furdan } \\
\text { Manco- } \\
\text { zebe }\end{array}$ \\
\hline $\begin{array}{l}\text { 1- acetone: ethyl } \\
\text { acetate:chloroform }\end{array}$ & $0.5: 1.5: 3$ & 0.90 & 0.98 & 0.85 & 0.88 & 0.90 \\
\hline 2-chloroform : ethyl acetate & $6: 1$ & 0.54 & 0.89 & 0.81 & 0.80 & 0.68 \\
\hline $\begin{array}{l}\text { 3- petroleum } \\
\text { ether:ethylacetate : methanol }\end{array}$ & $3: 1: 1$ & 0.45 & 0.85 & 0.92 & 0.66 & 0.90 \\
\hline $\begin{array}{l}\text { 4-peteroleum ether } \\
\text { ethylacetate }\end{array}$ & $3: 4$ & 0.85 & 0.95 & 0.84 & 0.72 & 0.79 \\
\hline $\begin{array}{l}\text { 5- chloroform: methanol } \\
\text { 6- acetone: petroleum ether: } \\
\text { ethyl acetate }\end{array}$ & $0.5: 2: 4$ & 0.45 & 0.88 & 0.73 & 0.82 & 0.91 \\
\hline $\begin{array}{l}\text { 7- petroleum ether: } \\
\text { Acetonitrile :methanol }\end{array}$ & $4: 2: 1$ & 0.48 & 0.94 & 0.87 & 0.54 & 0.53 \\
\hline
\end{tabular}

- Using the detection methods iodine vapor 
Ghazy, Yasmin A. et al.

Table (5): Thin-layer chromatographic analysis of different pesticides tested and their mixtures with peanut, sunflower and linseed oil extracts.

\begin{tabular}{|c|c|c|c|}
\hline \multicolumn{4}{|c|}{ - } \\
\hline \multicolumn{2}{|l|}{ A } & \multicolumn{2}{|l|}{ B } \\
\hline Pesticides & RF values & Pesticides & RF values \\
\hline 1- methomyl & 0.85 & 1- methomyl & 0.45 \\
\hline methomyl (P) & 0.85 & methomyl (P) & 0.45 \\
\hline methomyl (L) & 0.85 & methomyl (L) & 0.45 \\
\hline methomyl (S) & 0.85 & methomyl (S) & 0.45 \\
\hline 2- lambda* & 0.95 & 2- lambda & 0.88 \\
\hline Lambda* (P) & 0.95 & Lambda (P) & 0.88 \\
\hline Lambda* (L) & 0.95 & Lambda (L) & 0.88 \\
\hline 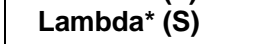 & 0.95 & Lambda (S) & 0.88 \\
\hline 3-Chloropyrifos & 0.84 & 3- Chloropyrifos & 0.72 \\
\hline Chloropyrifos (P) & 0.84 & Chloropyrifos (P) & 0.72 \\
\hline Chloropyrifos (L) & 0.84 & Chloropyrifos (L) & 0.72 \\
\hline Chloropyrifos (S) & 0.84 & Chloropyrifos (S) & 0.72 \\
\hline 4- Furdan & 0.72 & 4- Furadan & 0.82 \\
\hline Furdan (P) & 0.72 & Furadan (P) & 0.82 \\
\hline Furdan (L) & 0.72 & Furadan (L) & 0.82 \\
\hline Furdan (S) & 0.72 & Furadan (S) & 0.82 \\
\hline 5- Mancozeb & 0.79 & 5- Mancozeb & 0.91 \\
\hline Mancozeb (P) & 0.79 & Mancozeb (P) & 0.91 \\
\hline Mancozeb (L) & 0.79 & Mancozeb (L) & 0.91 \\
\hline Mancozeb (S) & 0.79 & Mancozeb (S) & 0.91 \\
\hline
\end{tabular}

A ----- petroleum ether: ethyl acetate (3: 4).

B - --1 petroleum ether: acetone: ethyl acetate (0.5:2:4)

* lambda- cyhalothrin

\section{5- Effects on Acetyl cholinesterase activity:}

The results showed that, Acetyl cholinesterase in serum extracted from horse blood was significantly decreased with compound witch one followed by Chloropyrifos, Mancozeb, Lambda, furdan and oil peanut values of 77.8 , $63,48.8,18.6$ and $11.1 \%$ respectively compared with control. As reported by Bayoumi et al. (1994); Karanth et al. (2003) and Saleh (1990).

Table (6): Effect of different pesticides On ACHE activity of Horse blood serum:

\begin{tabular}{|l|c|c|c|c|}
\hline \multicolumn{5}{|c|}{ ACHE Activity (\%) } \\
\hline \multicolumn{1}{|c|}{ Treatment } & $\begin{array}{c}\mathbf{1 / 1 0} \\
\mathbf{\mu g} / \mathbf{L}\end{array}$ & $\begin{array}{c}\mathbf{1 / 1 0 0} \\
\mathbf{\mu g} / \mathbf{L}\end{array}$ & $\begin{array}{c}\mathbf{1 / 2 0 0} \\
\boldsymbol{\mu g} / \mathbf{L}\end{array}$ & $\begin{array}{c}\mathbf{1 / 4 0 0} \\
\boldsymbol{\mu g} / \mathbf{L}\end{array}$ \\
\hline Chloropyrifos & 77.8 & 72 & 68.1 & 64.9 \\
\hline Mancozeb & 63 & 61 & 60.1 & 59.3 \\
\hline Lambda-cyhalothrin & 48.8 & 41.9 & 38 & 35.2 \\
\hline Furdan & 18.6 & 16.6 & 14 & 11.1 \\
\hline Oil peanut & 11.1 & 8 & 5.9 & 4.8 \\
\hline
\end{tabular}


The joint action effects resulting from mixing oil peanut with the tested compounds are shown in table (11). The serum cholinesterase activity was significantly decreased with all mixture.

From the previous results it was evident that the residues of pesticides tested in oils of peanut most be take most attention because of synergistic effect of this oil or their toxicity which can effect on human health.

Table (7): Effect of Binary mixture On ACHE activity of Horse blood serum:

\begin{tabular}{|l|c|c|}
\hline \multicolumn{1}{|c|}{ Treatment } & $\begin{array}{c}\text { Inhibition }(\%) \text { at } \\
\mathbf{1 / 1 0} \mathbf{\mu g} / \mathbf{L}\end{array}$ & $\begin{array}{c}\text { Inhibition of Mixture (\%) at } \\
\mathbf{1 / 1 0} \boldsymbol{\mu g} / \mathbf{L}\end{array}$ \\
\hline Control & 100 & 100 \\
\hline Chloropyrifos & 77.8 & 46.4 \\
\hline Mancozeb & 63 & 51.9 \\
\hline Lambda-cyhalothrin & 48.8 & 76 \\
\hline Furdan & 18.6 & 1.9 \\
\hline
\end{tabular}

\section{REFERENCES}

Abbott, W. S. (1925). A method of computing the effectiveness of an insecticide. J. Entomol, 18 (2): $265-67$.

Ashry, M. A.; O. C. Bayomi; M. F. Shady and M. A. Khalifa (1991). Stability of some pesticides in combination with two foliar fertilizers and their toxic effects towards Pigomia mixta and Spodoptera Littoralis biosd. J. Agric. Res. Tanta Univ. 17 (3): 767-774.

Bayoumi, O. C.; A. Abdel-zeez; K.H. Khilo; S.A. El-fikey and Sh.A. Hemeda (1994). Hepato- renal and cytogenetic studies on the effect of the inseciticide chloropyrifos, the foliar fertilizer, FF and for their mixture on rats.

Bayoumi, O.C.; B. Schiffers and J. Fraselle (1983). Chromatographic determination of carbofuran and 3-hydroxy carbofuran in plants soil water and artificial diet of Mysus Persicae. J. Med. Fac. Landbouww. Rijks. Univ. Gent. 48 (4): 1007-1014.

Bayoumi, O.C., N. L. Kelada and N. shaker (1988). Toxic effects of some carbamate insecticide and their major metabolites against culex pipiens I. bull. Rech. Agron. Gembloux 23 (1): 67-75.

Costa , M.F., H.M. Gattosfosse, and B.R. Guillet (1968). Utilization des argumes dans lindistrie aliaentraire et pharmaeceutique. Fruits (paris) 23 (10) 531-541.

El-Defrawi, M.E., A.A. El-Bahrawi, A. Toppozada, and M. Zeid (1964). Toxicological studies on the Egyption cotton leafworm, Prodenia Litura I.V. The toxicity of Pyrethrins, and Cyclethrin to prodenia larvae and effect of synergistic. J. Econ. Entomology. 58 (1) 93-98

Gupta, BM. and C.P.S. Yadava (1986). Studies on insect pests of cumin and their control. Indian,Coca., Arecanut and Spices Jornal, 9 (3): 70-71.

Karanth,-S; ,-J; Liu-K,-Jr; Olivier, ,-C Pope (2004). Interactive toxicity of the organophosphorus insecticides chlorpyrifos and methyl parathion in adult rats. Toxicology-and-Applied-Pharmacology. 2004; 196(2): 183190 
Ghazy, Yasmin A. et al.

Litchfield, J. T. Jr., and F. Wilcoxon (1949). A simplified method of evolution of dose effect experiments. J. Pharmacology. Exp. THER., 95: 99-113.

Saleh, F. (1990). Metabolic effects of carbamate insecticide ( methomyl) on rats: II Changes in serum cholinesterase and transaminases following treatment of the insecticide. J. Phys. Sci., 14 (1-2): 55-64.

Souza,-K-R-de; ,-L-J; McVeigh,-D-J Wright (1992). Selection of insecticides for lure and kill studies against Spodoptera littoralis (Lepidoptera: Noctuidae). Journal-of-Economic-Entomology. 1992; 85(6): 2100-2106.

Swisher, H.E. and D.E. Pritchett (1969). Flavor enhancement of bakery goods with citrus products. Baker's. Dig. 43 (3) 53 - 55, 77.

Waber, H. D. M. W. (1966). Kinetic colorimetric method for cholinesterase activity. 91: 1927.

Watson,-W-M; ,-Z-H Zidan (1983). The joint action of certain pesticide combinations on Spodoptera littoralis.

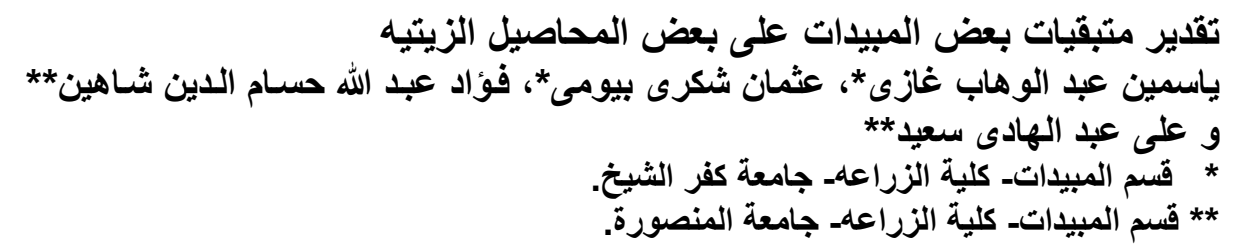

موضوع هذا البحث أستهف دراسة التأتير السام لبعض المركبات وهى مبيد اللمباداد و الفيوردان و

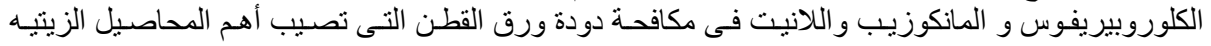
ومنها الفول السودانى و عباد الثمس و الكتانئ. تم الحصول على بذور هذه المحاصيل المعامله والغير المعامله و اجراء التجارب عليها لأستخلاص الزيت منها وتقدير متبقيات المبيدات بها.

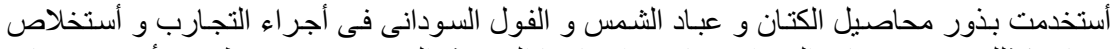

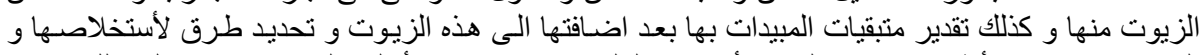

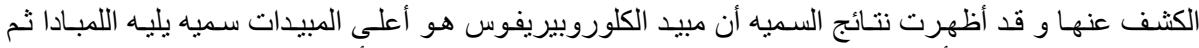

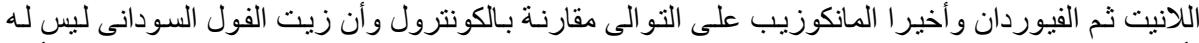

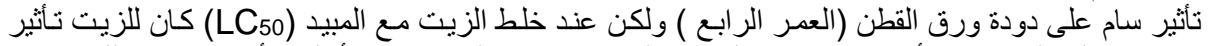

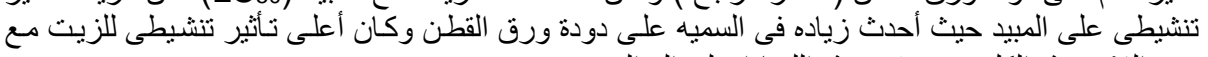

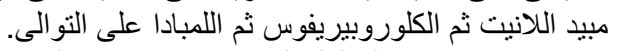

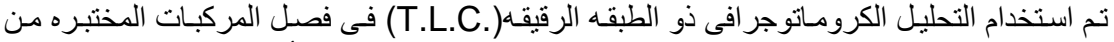

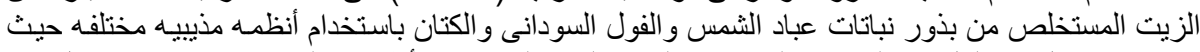

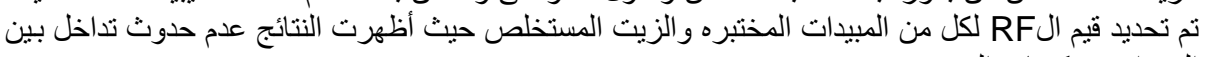

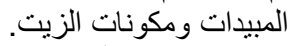

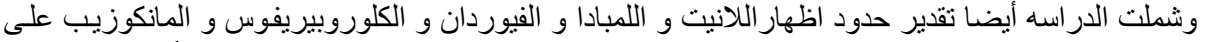

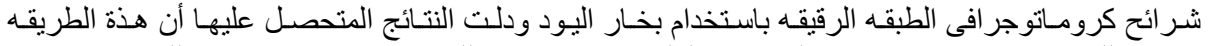

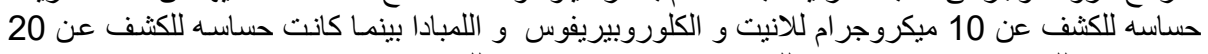

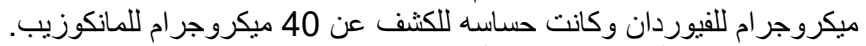

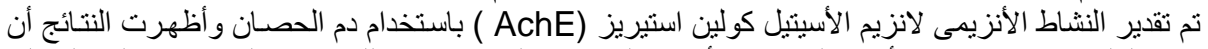

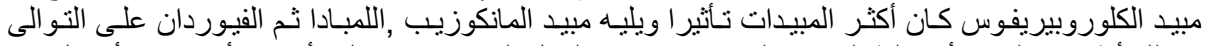

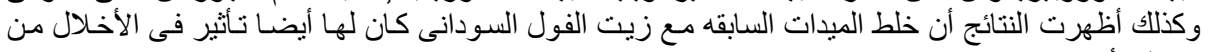

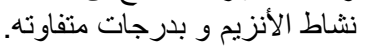

